\title{
Rosalind and Śakuntalā among the Ascetics: Reading Gender and Female Sexual Agency in a Bengali Adaptation of As You Like It
}

\begin{abstract}
My article examines how the staging of gender and sexuality in Shakespeare's play As You Like It is negotiated in a Bengali adaptation, Ananga-Rangini (1897) by the little-known playwright Annadaprasad Basu. The Bengali adaptation does not assume the boy actor's embodied performance as essential to its construction of the Rosalindequivalent, and thereby it misses several of the accents on gender and sexuality that characterize Shakespeare's play. The Bengali adaptation, while accommodating much of Rosalind's flamboyance, is more insistent upon the heteronormative closure and reconfigures the Rosalind-character as an acquiescent lover/wife. Further, Ananga-Rangini incorporates resonances of the classical Sanskrit play Abhijñānaśākuntalam by Kālidāsa, thus suggesting a thematic interaction between the two texts and giving a concrete shape to the comparison between Shakespeare and Kālidāsa that formed a favourite topic of literary debate in colonial Bengal. The article takes into account how the Bengali adaptation of As You Like It may be influenced by the gender politics informing Abhijñānaśākuntalam and by the reception of this Sanskrit play in colonial Bengal.
\end{abstract}

Keywords: As You Like It, $19^{\text {th }}$-century Bengali theatre, cross-dressed heroine, female sexual agency, Kālidāsa, classical Sanskrit drama.

My article appraises a $19^{\text {th }}$-century Bengali adaptation of As You Like It in the light of some key observations on homoeroticism and female sexual agency that have emerged from commentators on Shakespeare's cross-dressed heroines over the last three decades. My article further tries to demonstrate how this Bengali play, Ananga-Rangini, registers echoes of, and enters into a dialogue with, a text originating in a different noetic regime from Shakespeare's. The text in question is the classical Sanskrit play Abhijñānaśäkuntalam ["The Signet Ring of Śakuntalā"] or Śakuntalā by Kālidāsa, who is "widely acknowledged as the supreme poet and playwright of the classical Sanskrit tradition" (Johnson ix) and

* Jadavpur University, West Bengal, India. 
was active between 400 to $500 \mathrm{CE}$ (Sengupta and Tandon 4). This article will try to contextualize why As You Like It has been neglected as a performance text in the Bengali theatre, taking into account the representation of transvestism and female sexuality in Shakespeare's play. The article will then examine how Ananga-Rangini adapts As You Like It, with particular attention to the expressions of female sexual desire and agency in these two plays. In the final section, the article will locate the resonances of Abhijñanassākuntalam in Ananga-Rangini and examine how the interactions between the Shakespearean and the classical Sanskrit text help bring the Rosalind-equivalent of the Bengali play closer to the contemporary Bengali expectations of femininity.

\section{The Neglect of As You Like It in Bengali Theatre}

The title page of the Bengali play Ananga-Rangini [“Ananga and Rangini”] by Annadaprasad Basu has the descriptive tag within parentheses, milananta natak ["a play ending in union"], followed by the acknowledgement, mahakavi Shakespearer "As You Like It" namak nataker chhaya avalambane [literally, "based on the shadow of the master-poet Shakespeare's play named As You Like $I t$ ']. Ananga-Rangini may be identified as an indigenized adaptation, or what Nazmul Ahsan calls a "cultural translation" of the comedy by Shakespeare (xii). This play exhibits "the localization of names and places, the addition of song and dance, adaptation of plot, and even interpolation of characters and scenes" that comprised the routine for "indigenized staging of Shakespeare in India" (Trivedi 153), although there is no record of this play being performed.

When Annadaprasad Basu published this adaptation of As You Like It in 1897, there had already been a substantial history of Shakespeare reception in Bengali from the early $19^{\text {th }}$ century. There were two main channels for the dissemination of Shakespeare to a Bengali-speaking audience: first, "a new educational curriculum [introduced and sponsored by the British colonial regime] designed for the training of the native bourgeoisie"; and second, the Bengali public stage, which tapped Shakespeare as a repository of "plots and characters that could be freely adapted and repurposed" (Supriya Chaudhuri 102). Reflecting on the Western-educated Bengali audience's interaction with Shakespeare, R. K. DasGupta finds that

[m]ore important than [the] circumstantial influence of Shakespeare on the dramatic technique [of the nascent Western-style Bengali commercial theatre] is the influence of the English poet on the nineteenth century Bengali mind. [...] It was through his great tragedies that we came to realize that there was a great literature other than our own and in many ways different from it. We discovered the difference and yet acknowledged its greatness. (25) 
One of the several indices of this intellectual engagement would be found in the $19^{\text {th }}$-century Bengali adaptations of Shakespeare, which were attempted by the Western-educated Bengalis but did not necessarily presuppose the Bengali audience's earlier acquaintance with Shakespeare.

Prior to the publication of Ananga-Rangini, there had been in print at least 23 dramatic adaptations or translations of Shakespeare in Bengali, whether or not they were actually staged (Mitra 198-99). This estimate does not take into account the paraphrases and novelizations of Shakespeare's plays in Bengali. This tally also leaves out "a translation into Bengalee, of Shakespeare's tragedy of the Tempest [sic]" that was executed by one Mr. Monckton, a Briton and prospective civil servant, at the Fort William College, Kolkata (formerly Calcutta) in 1809 (Roebuck 187). Now lost, this is the first recorded translation of Shakespeare in Bengali (Mitra 198). The same year as the publication of Ananga-Rangini saw the staging of Hariraj, based on Hamlet, written by Nagendranath Chaudhury and available in print since 1896 (Mitra 52-55; Raha 76). It proved to be the most popular and lucrative adaptation of a Shakespeare play, whether a comedy or a tragedy, for the $19^{\text {th }}$-century Bengali theatre.

R. K. DasGupta in his observations quoted above registers Shakespeare's momentous impact on the Bengali intellectual almost exclusively in terms of his tragedies, and this emphasis on the tragedies is quite apposite because Shakespeare was probably the single-most important Western author to catalyze the inception of a tragic vision in Indian dramaturgy (Das 110). As R.K. Yajnik reminds, the "Hindu philosophy" that governed ancient India drama "does not lead to a great tragedy," and it was in Shakespeare that the Indian student "came across a profound study of the genuine tragic atmosphere" and found Shakespeare's mode of tragedy "particularly impressive" (152). However, the comedies and romances of Shakespeare were also adequately represented among the Bengali translations and adaptations of Shakespeare in the $19^{\text {th }}$ century. On the other hand, the history plays were entirely ignored for Bengali adaptations. In fact, 10 out of the tally of 23 published texts mentioned earlier are adaptations of comedies (The Comedy of Errors, A Midsummer Night's Dream, The Merchant of Venice) and romances (Cymbeline, The Tempest, The Winter's Tale). However, Annadaprasad Basu's text seems to have been the only dramatic adaptation of As You Like It up to that time in Bengali. It would be followed by a faithful Bengali translation of Shakespeare's play (retaining the original characters and cultural setting) only in 1923, namely, Maner Matan by Saurindramohan Mukhopadhyay. There is also no evidence for the staging of Ananga-Rangini itself (Datta 169), although it was published during the heyday of the public theatre in Kolkata. Moreover, the 1923 translation of As You Like It was primarily targeted at a reading audience and in all probability it was never performed. Another faithful translation of the play, by Sunilkuamr Chattopadhyay (published 1957), appears to have had the same fate. Even 
a more recent Bengali translation of the play by Abu Shahriyar (entitled Apnar Jeman Pachhanda, published 2012) is too prosaic and does not seem to be meant for a stage production.

The absence of a stage history for Ananga-Rangini seems to be an anomaly, since the text of the play reflects knowledge of contemporary staging conventions-with its clear demarcation of acts and scenes, full delineation of entrances and exits and precise inclusion of stage directions. The play also appears to be eminently stage-worthy in terms of the language, characterization and its handling of the action. This can hardly be said of several earlier dramatic adaptations of Shakespeare, for example, Hurro Chunder Ghose's unstaged plays Bhanumati-Chittavilas Natak (published 1853, an adaptation of The Merchant of Venice) and Charumukh-Chittahara Natak (published 1864, an adaptation of Romeo and Juliet) (Rina Ghosh 56-63), or a play that was actually performed in the public theatre, Lakshminarayan Chakraborty's Nanda-bangshochchhed (published 1873, an adaptation of Hamlet). Although no performance history is available for Ananga-Rangini, one may treat it as a potential performance text, relating the play to contemporary performance conventions and the stage history of As You Like It. This can help resist at least partially "the logocentricity that continues to be affirmed in the 'dramatic text', which curiously survives the onslaught of deconstructive performative strategies, non-verbalism, physical theatre, invisible theatre, and a spate of non-textual activist interventions and infiltrations" (Bharucha 85-86).

This noticeable omission or negligence that fell to the lot of As You Like It enables the conjecture that the play did not appear compatible enough with the taste or competence of the Bengali adaptor, whether or not aiming for the stage. This phenomenon may be partially traced to Shakespeare's experiment with transvestism, gender and sexuality in As You Like It, which demands a level of cultural competence on the part of the audience for its adequate appreciation. To be sure, other plays by Shakespeare featuring cross-dressing heroines had been adapted in Bengali earlier than Ananga-Rangini. Hurro Chunder Ghose's Bhanumati-Chittavilas Natak, which may be recognized as the earliest extant and officially acknowledged dramatic adaptation of Shakespeare in Bengali, is in fact based on The Merchant of Venice. Before the publication of AnangaRangini there had been another Bengali adaptation of The Merchant of Venice, namely, Suralata by Pyarilal Mukhopadhyay, published 1877 (Mitra 197). There also had been two adaptations of Cymbeline in Bengali before 1897, namely, Susheela Veersingha Natak by Satyendranath Tagore (published 1868) and Kusumkumari Natak by Chandrakali Ghosh (published 1868) (Mitra 196). The latter was also commercially produced in the Bengali public theatre as early as 1874 (Lal and Chaudhuri 96-97). But it needs to be recalled that The Merchant of Venice and Cymbeline do not capitalize upon the heroine's transvestism for the greater part of their lengths or attempt prestidigitation over gender and 
sexuality to the same extent as As You Like It. According to Lal and Chaudhuri's survey, none of Shakespeare's plays featuring transvestite heroines appeared on the Bengali stage in the $19^{\text {th }}$ century-except for the adaptation of Cymbeline (a sombre play with a long-suffering and less than ebullient heroine). Besides, no Bengali adaptation of The Merchant of Venice would be commercially produced earlier than Bhupendranath Bandyopadhyay's Saodagar in 1915 (Lal and Chaudhuri 103). More curiously, the only major Bengali staging of As You Like It in the Kolkata-based Bengali theatre seems to have taken place as late as 2012. The production in question, Hridmajhare ["In the Middle of the Heart"], was staged by the troupe Nandikar using a tailor-made translation-adaptation by Kanchan Amin, and directed by Supriyo Chakraborty, Sohini Sengupta and Kamal Chattopadhyay.

Going by this estimate, one may surmise that some features of these cross-dressing comedies of Shakespeare, such as their ludic exploration of gender and sexuality, and their insistent exploitation of the device of the doubly cross-dressed boy actor of Shakespeare's own stage, did not agree with the horizon of expectations that the newly established theatrical practice of $19^{\text {th }}$-century Kolkata catered to. According to one line of argument about Shakespeare's stage, the boy actor's body was not an invisible feedstock for the theatrical construction of female identity, but a key source of aesthetic/sexual stimuli and signification (Jardine 9-36; Callaghan 31-32; Sedinger 67-75). Male transvestism would be leveraged in Shakespeare's comic theatre through "references, implicit or explicit, to the body beneath that of the actor's impersonation (including scenes of broad, bawdy humour); excessive attention to the age, beauty and apparel of the cross-dressed boy, and especially to the complex sexual appeal of boy actors twice cross-dressed" (Zimmerman 47). These devices could not be replicated on the Kolkata stage. One of the hallmarks of the Western-style Bengali commercial theatre introduced in $19^{\text {th }}$-century Kolkata was the deployment of actresses for female roles, itself a groundbreaking and tendentious move, as opposed to the all-male cast of traditional Bengali theatre forms such as the jatra (Raha 30-31; Dutt and Sarkar Munsi 49-53, 122-23). The presence of the actresses on the Bengali stage would rule out at least one level of the metatheatrical jokes in As You Like It surrounding the doubly cross-dressed or reverse-cross-dressed boy actor in Shakespeare's all-male theatre. Comparably, it is on record that the "earliest instance of Shakespeare being inducted into a folk form [in India] is found in the 1860s in a script of As You Like It in the yakshagana form" of the Karnataka region of southern India (Trivedi 153), which is traditionally enacted by an all-male troupe. However, one also has to review the surmise that As You Like It was neglected by Bengali adaptors simply because they did not have in mind a theatre with female impersonators (like Shakespeare's own). This speculation fails to explain why As You Like It was a favourite on the English commercial 
stage (which deployed actresses from 1660 onwards) and why Rosalind was a role much coveted by a succession of leading ladies in the Anglophone world (Latham lxxxvii-xc; Dusinberre 13-26). This problem will be taken up shortly.

\section{Rosalind's Bengali Avatar and the Question of Sexuality}

With respect to the number of lines, the role of Rosalind is the longest among women characters in Shakespeare's dramatic corpus (Richmond 43). It is perhaps also the most fraught and challenging role counting all of Shakespeare's cross-dressed heroines since it plays off against each other four layers of identity or performative functions: (i) the tacit one of the boy actor essaying the female role of Rosalind in Shakespeare's theatre, (ii) Rosalind, (iii) Rosalind masquerading as the garrulous boy named Ganymede in the forest of Ardenne, and (iv) Rosalind as Ganymede playing the caricature of herself in a game of make-believe to cure Orlando of his lovesickness and advance her love with him. According to Phyllis Rackin, "the ambiguities of the conclusion to that play involve not only gender but sex itself, and not only the character Rosalind but also the boy actor who played her part" (36). As opposed to this, the Bengali adaptation, which seeks to transpose Shakespeare's play to an Indian or Bengali frame of reference, does not or cannot exploit the substratum of the boy actor's embodied performance for its construction of the cross-dressed heroine. It thereby misses several of the inflections on gender and sexuality that inform the original play.

In the Bengali adaptation, Shakespeare's Rosalind is rechristened as the Rangini of the title, the name reflecting the playfulness and ebullience of the original character. The Samsad Bengali-English Dictionary (1968) glosses the Sanskrit-derived Bengali word rangini as a feminine adjective meaning "jocular, gay, frolicsome, sportive, taking frenzied delight in," and also, at the dark end of the spectrum, "wanton" (1084). The male lead, Orlando, is adapted as Ananga, which is another name for Madana or Kamadeva, the god of love in the Hindu pantheon. The name is thus suggestive of the character's physical beauty as well as amorousness. If the word anangarangini is taken as a compound adjective (the original Bengali title does not have the intervening hyphen used in this article for the sake of clarity and disambiguation), it would signify a woman "who takes a frenetic delight in love." This description would apply to Rangini, but only partially, since her boldness and playfulness are finally contained by the play to suit the model of the dutiful wife. When Rangini cross-dresses for exile, she assumes the name of Jnan. This is meant to recollect aurally Shakespeare's Ganymede, but the Sanskrit word jnan ["wisdom"] cannot encompass the homoerotic connotations of Rosalind's alias. The boy Ganymede is Jupiter's cup-bearer and love interest in classical mythology, which made the name quite 
familiar in early modern English literature on same-sex love between men (Dusinberre 9-11). Further, the name along with its derivative catamite served as a catchword in Shakespeare's England for a boy or young man who sold his sexual favours to older men as a passive recipient of anal intercourse (Orgel 496-97; Brown 251-56). The Bengali adaptation's cultural milieu hardly afforded any space for relishing or even acknowledging this risqué association, and it was therefore wisely avoided by the play.

In Shakespeare's play As You Like It homoerotic frisson is generated on the level of the verbal text by two sets of interactions, the first between Ganymede and Orlando, and the second between Phoebe and Ganymede (although Phoebe's amorous feelings for Ganymede are unreciprocated). At the same time, it also needs to be acknowledged that Shakespeare's play offers ample opportunity for containing or bypassing the homoerotic possibilities inherent in it, which is the reason why the play has worked over the centuries with an exclusively or predominantly heterosexual interpretation. The PhoebeGanymede interaction can be made to lose its erotic intensity by being cast in the farcical model of an obtuse woman's amorous delusions. As in Shakespeare's play, Rangini is hyperbolically dismissive of the Phoebe-equivalent, named Phullara in the adaptation, and calls her abusive names such as Chandi [a fierce, destructive form of the Hindu mother goddess] and Shurpanakha [an amorous female demon in the Rāmāyana] (Annadaprasad Basu 93, 94).

Towards the end of Shakespeare's play, Ganymede asks Orlando: "Why then tomorrow I cannot serve your turn for Rosalind?" (5:2:43-44) The question, coming from a person whom Orlando takes to be a sexually knowledgeable boy, can be construed on one level as an invitation to a same-sex coitus, although the theatrical irony involving Ganymede's real identity as a woman character within the fictional economy of the play would be entirely clear to the audience. The Bengali play retains the line, but does not highlight its risqué possibilities (Annadaprasad Basu 112). This is probably because the late $19^{\text {th }}$-century author was diffident about bringing in a joke about male-male intercourse. Incidentally, the homoerotic potential of Ganymede's proposition has been exploited in a recent Bengali adaptation of the play, Hridmajhare produced by Nandikar in 2012. In that play, the Orlando-equivalent is scandalized and protests vociferously when he suspects the Ganymede-equivalent to be a man having sexual designs on him. But Ananga-Rangini does not toe that path. In fact, Rangini reveals her true identity not in a moment of well-calculated triumph but is compelled to do so as a restorative measure when the already-wounded Ananga is in the throes of a fever and disconsolately pining for Rangini (Annadaprasad Basu 112). More importantly, Ananga-Rangini totally discards the Epilogue of Shakespeare's play, which is spoken by Rosalind drawing attention to the boy actor playing the role and revelling in the confusion of gender and sexual propensities (Rackin 36-37, 39). 
It becomes thus evident that Ananga-Rangini is incapable of juggling the resources of homoeroticism or cross-dressing in a self-conscious and aesthetically motivated way. One needs to bring in a timely proviso to qualify the picture. Which is to say, the convention of all-male acting or cross-dressing in traditional or folk theatre would hardly be unknown to the $19^{\text {th }}$-century Bengali audience. Besides, there is increasing evidence that homoeroticism or homosexuality, although largely muted or marginalized, was not entirely alien to the archive of Bengali experience (Bhaskar Chaudhuri 151-64, 209-21). These two issues are brought together in some oblique comments made by Girish Chandra Ghosh (1844-1912), the greatest ever actor-manager of Bengali theatre and the most successful playwright of his time, in an article originally published in the magazine Rangalay ["The Theatre"] in 1901. The title of the article is Purush Angshe Nari Abhinetri ["Actresses in Male Roles"]. Although Girish was a Shakespeare aficionado all his life and had also proclaimed the similarity of his own theatrical practice with Shakespeare's artistic credo, he completely rubbishes all-male or cross-dress acting. He calls it an anomaly, which committed theatre-practitioners should avoid. Girish also objects to Sarah Bernhardt's famous portrayal of Hamlet in 1899 (821-22). He in the same article finds faults with Binodini Dasi's transvestite performance as the $16^{\text {th }}$-century Vaishnavite mystic Sree Chaitanya Mahaprabhu in the 1884 play Chaitanya Leela written and directed by Girish himself (820), a performance that took the spiritual life of Bengali Hindus by storm (Gangopadhyay 197-98). Girish's peroration in the article is quite revelatory and may be quoted at some length.

Some critics, citing the example of the dohars [chorus boys] belonging to the jatra troupes, advise that boys should be cast in female roles. It appears that such critics have never seen jatra performances. If they had, they would never blame the managers of public playhouses [like Girish himself, for hiring actresses] even in the name of religious strictures. Some religious groups have on some occasions mounted amateur performances deploying boys [for female roles]. If the detractors [of public theatre] have enjoyed such performances, only they can explain why they have. Certainly, the majority of the playgoers will not sympathize with them. (823)

Girish's stance towards the supporters of all-male acting becomes especially admonitory when he takes up the topic of boys cast in female roles:

Those who advocate all-male performances should keep their views to themselves. Otherwise, dramatic performances will never improve in Bengal; and the boys who will unfortunately have to essay female roles will have to stay as women within male bodies for the rest of their lives. (823; emphasis added) 
Girish ends his article on a rather grave and disconcerting note as he avers, "We can give examples for this, but we do not agree to identify and expose them who still inhabit a woman-like state after essaying female roles in their boyhood. It is easy to understand that boyhood habits die hard. If one does not see reason, we cannot help" (823; emphasis added). In view of this sentiment, Ananga-Rangini can be seen as taking a rather informed and guarded stance about the staging of homoerotic frisson while also trying to accommodate Shakespeare's comic idiom.

Incidentally, Girish adapted for the Bengali stage at least three famous Bengali novels that feature transvestite roles or sequences: Bakimchandra Chattopadhyay's Kapalkundala (staged 1873), Bankim's Bishabriksha (staged 1878) and Romesh Chunder Dutt's Madhabikankan (staged 1881). All these novels have intense tragic overtones and do not admit of the effervescent comicality of As You Like It. More importantly, Girish later includes a transvestite heroine in his tragic play Bishad (produced 1888). It revolves around Saraswati, the king of Ayodhya's neglected wife who takes the disguise of a boy named Bishad [meaning "melancholy" in Sanskrit] in order to serve the (female) prostitute with whom her husband cohabits, and finally sacrifices her life for him. The role reminded the $20^{\text {th }}$-century scholars Sukumar Sen of Bellario/ Euphrasia in Beaumont and Fletcher's tragi-comedy Philaster (333), and Devipada Bhattacharya of Sebastian/Julia, Cesario/Viola and Fidele/Innogen in Shakespeare's plays The Gentlemen of Verona, Twelfth Night and Cymbeline respectively (xlv). All these characters from early modern English plays are hospitable to homoerotic resonances at multiple levels, and in fact Girish's own play generates tantalizing homoerotic confusions as both the husband and the prostitute feel drawn towards the boy servant Bishad. However, the reviewers in contemporary periodicals ignored such possibilities. What they appreciated instead was the depiction of Saraswati as the paragon of chastity and wifely devotion, befitting the highest patriarchal ideals of Hinduism (Gangopadhyay 236-37). It is again noteworthy that the two $20^{\text {th }}$-century scholars who liken Bishad with early modern English characters do not mention Ganymede/ Rosalind, presumably because Rosalind is far more playful than these characters and she shares none of their dejection.

One may also add here that a lesser-known Sanskrit play, Viddhaśālabhañjikā ["The Carved Female Statue"] by Rājaśekhara (late $9^{\text {th }}$ century to early $10^{\text {th }}$ century CE), features a transvestite heroine and the plot revolves around the confusion over her gender. The play also has a comic subplot featuring the mock-marriage of a court jester with a boy dressed as a woman, reminiscent of Ben Jonson's comedy Epicoene, or The Silent Woman (Gray 4). But the Sanskrit play does not try to explore questions of gender and sexuality (at least to the extent As You Like It does), does not present the heroine on the stage for the greater part of its duration (Gray 6) and follows a clear 
heteronormative trajectory. The play was available in an English paraphrase by the Orientalist scholar Horace Hayman Wilson (354-60) from the early $19^{\text {th }}$ century. Besides, a scholarly edition of the play in the Devanagari script was published from Kolkata in 1883 with annotation and commentary by Jibananda Vidyasagara, the then Superintendent of the Sanskrit College, Kolkata. The play was first fully translated into English in 1906 (Gray 1), and a Bengali translation by Jyotirindranath Tagore (1849-1925) was published in 1310 BS or 1903-4 CE (Manmathanath Ghosh 158). But Viddhaśälabhañjikā does not seem to have been widely known among the Shakespeare-reading Bengali audience. The play is not mentioned in comparative studies of Shakespeare and classical Sanskrit drama that occur regularly in the Bengali periodicals of the late $19^{\text {th }}$ and early $20^{\text {th }}$ centuries, and does not seem to have inspired the creation of transvestite heroines for the Bengali commercial stage.

One may hazard the guess that it is the characterization of Rosalind as a strong-willed, loquacious and playful woman, and not the homoerotic overtones of the character, that proved to be the foremost reason why the Bengali readers and adaptors were not much fond of the character. This is further supported by the fact that As You Like It did not elicit much attention from Bengali commentators on Shakespeare, although it was established in the Anglophone world as a major comedy by the $19^{\text {th }}$ century. The inclusion of the play in college curricula testifies to its canonicity in colonial Bengal. The Calcutta University Calendar; 1871-72 shows that a question paper for the Honours examination in English asks the students to explain the lines from As You Like It, "You must borrow me Gargantua's mouth first" (3:2:205) and "... that which here stands up / Is but a quintain" (1:2:216-17), spoken by Celia and Orlando respectively (cxxvii). The same examination back in 1870 demanded, "In what does the peculiar charm of 'As You Like It' appear to you to consist?" (Calendar for 1870-71; cxxvii).

However, the favourite Shakespeare play for late- $19^{\text {th }}$ - and early- $20^{\text {th }}$ century Bengali critics is evidently The Tempest. It generated comments from a galaxy of literati including Bankimchandra Chattopadhyay (1838-94), Haraprasad Shastri (1853-1931), Priyanath Sen (1854-1916), Hirendranath Dutta (1860-1942), Balendranath Tagore (1870-99) and Lalitkumar Bandyopadhyay (1868-1929), apart from Rabindranath Tagore (1861-1941) himself (Mitra 18794). What is more, Srishchandra Majumder (1860-1908), Sudhindranath Tagore (1869-1929) and Kshirodbihari Chattopadhyay produced full-fledged journal articles comparing Miranda with the eponymous heroine of Bankimchandra Chattopadhyay's novel Kapalkundala (1866), treating the two characters as variations on the theme of feminine innocence and purity. One would be hard put to find even a stray afterthought on Rosalind coming from them. Haraprasad Shastri considers such diverse female characters as Miranda, Desdemona, Dame Quickly, Cleopatra and Lady Macbeth (139), but does not take Rosalind into 
account. In a serialized essay on Shakespeare, the philosopher, politician and educationist Hirendranath Dutta mentions Rosalind twice in passing to illustrate the variety and distinctiveness of Shakespeare's women characters, also mentioning in the same breath such a wide assortment of characters as Titania, Miranda, Doll Tearsheet, Isabella, Catherine of Aragon, Cleopatra and Innogen (Shakespeare, 3:480) and Desdemona, Ophelia, Perdita, Portia, Emilia and Dame Quickly (Shakespeare, 3:482). Elsewhere, Hirendranath in his serialized comparative study of Shakespeare and Kälidāsa takes the examples of Cordelia, Innogen and Regan, but does not mention Rosalind (Kälidāsa o Shakespeare, 2: 244). This neglect towards Rosalind may be traced to the fact that Rosalind's playful disingenuousness and effervescent sexuality made her unfit to be stereotyped conveniently either as a socially inexperienced romantic heroine like Miranda, a menacing seductress like Cleopatra or an inhuman villainess like Regan.

One critic is of the opinion that in the Bengali adaptation under review Rangini and Sarala (the Celia-figure) have been rendered coy and naive in order to suit Bengali cultural expectations about pure, virginal young women (Rina Ghosh 199). But it may be demonstrated that the play amply retains in the character of Rangini much of Shakespeare's playful heroine and the frankness of her desire. For instance, Rosalind's racy rejoinder, "Some of it is for my child's father" (1:3:9) is replicated in Bengali (Annadaprasad Basu 26). Further, the Celia-equivalent named Sarala in the same scene apostrophizes in mock horror, "Ananga, wherever you are, rush in and fill my sister's belly at once, for she cannot stay empty-bellied anymore. If you are late, she may start biting at bricks out of sheer hunger" (Annadaprasad Basu 27). Such a frank celebration of female libido is not to be found even in Shakespeare's play. Since the Bengali adaptation dispenses with the character of Touchstone, Rangini and Sarala in fact remain the only purveyors of broad, earthy humour in it.

Nevertheless, the Bengali adaptation by and large emphasizes those parts of the play that ascribe a feminine core to Rosalind. Shakespeare's Rosalind, for example, protests, "Dost thou think, though I am caparisoned like a man, I have a doublet and hose in my disposition?" (3:2:178-80; emphasis added). The Bengali play renders this faithfully when, after guessing Ananga's presence in the forest retreat Rangini feels her passions as a woman aroused and asks Sarala, amar ange dhuti chadar bole antareo ki tai? ["I am wearing dhuti and chadar (like a $19^{\text {th }}$-century Bengali Hindu gentleman) on my body, but is my inside also like that?"] (Annadaprasad Basu 59).Rosalind finds her disguise to be a hindrance when she learns that her lover Orlando is present at Ardenne and cries, "Alas the day, what shall I do with my doublet and hose!" (3:2:200-1; emphasis added). Likewise, Rangini exclaims in the identical situation, Hari! Hari! E dhutichadarer phal ki? ["By Lord Hari! What use is the dhuti and chadar now?"] (Annadaprasad Basu 59). Rangini also repeats Rosalind's query, 
"But doth he know that I am in this forest, and in man's apparel?" (3:2:208-9; emphasis added). For all her swaggering and attitudinizing, the fact that Rosalind swoons on being shown the napkin soaked in Orlando's blood betrays her feminine self-an episode that is retained in the adaptation (Annadaprasad Basu 102). Further, the Bengali play, true to the horizon of expectations it presupposes, transmutes Rosalind into the traditional figure of an acquiescent and devoted wife even before she gets married. Unlike Shakespeare's jubilant heroine, after doffing her disguise Rangini remains silent out of compunction for having deceived Ananga for so long. Her cousin Sarala has to request Ananga on her behalf to pardon her (Annadaprasad Basu 118).

\section{Rosalind, Śakuntalā and Female Sexual Agency}

Ananga-Rangini invites comparison with Kālidāsa's Abhijñānaśākuntalam (c. $400 \mathrm{CE}$ - c. $500 \mathrm{CE}$ ) through its reconceptualization of the forest of Ardenne and its native denizens. Kālidāsa reworks a non-descript ākhyāna or narrative from the Ádiparva (Book I) of the Mahäbhärata to produce an engaging poetic play about (heterosexual) love, estrangement and reunion, which has been compared with Shakespeare's romance The Winter's Tale (Johnson x; Malagi 120-24). The plot of Abhijñannaśäkuntalam would be familiar to the $19^{\text {th }}$-century Bengali readers, thanks to the famous paraphrase by Ishwarchandra Vidyasagar (1820-91) entitled Śakuntalā (first published 1854), which was often prescribed for school syllabi. To summarize the play quickly, Dusyanta, king of the lunar dynasty of Puru, goes on a hunting expedition and meets the virginal beauty Śakuntalā (the natural daughter of the sage Viśvamitra and the apsarā or celestial nymph Menakā) at the hermitage of her foster-father, the sage Kanva. Duṣyanta and Śakuntalā fall in love with each other, get married hastily and secretly through the mutual exchange of vows and consummate their marriage, following which he leaves for his capital Hastināpura giving her a signet ring. Owing to the curse of the sage Durvāsas, when the pregnant Śakuntalā goes to the capital city she is unable to show the ring and Dușyanta fails to recognize her. Śakuntala is whisked away to heaven by her mother and gives birth to her son at the semicelestial hermitage of the sage Mārīca, where they are granted residence. When the lost signet ring is accidentally recovered, Dusyanta is full of repentance for the loss of Śakuntalā and despairs of having a son and heir. The play ends happily as Dușyanta is united with Śakuntala and their son at the hermitage of Mārīca. When Sir William Jones translated the play into English in 1789 under the title Sacontala; or, The Fatal Ring: An Indian Drama, it constituted a foundational text of the Orientalist project and "inaugurated the modern phase of the cultural relationship between India and the West" (Devy 26). It received enthusiastic attention especially from the German Romantics. 
The Bengali adaptation of As You Like It under review recalls the atmosphere of Abhijñanaśäkuntalam by showing the forest of Ardenne as a tapovan, a Sanskrit-derived term for a religious retreat or penance grove. This point has been mentioned in passing by Saubhik Datta in his doctoral dissertation (170). The honourable precedent of the Sanskrit play warrants the ascetic retreat to be used as a locus for love plots. Besides, the Bengali play also calls the forest dwellings ashram and introduces the Silvius-figure as a tapaskumar (young unmarried ascetic or hermit), the Phoebe-character as a tapaskumari (young unmarried ascetic woman) and the Corin-equivalent as an unnamed tapasvi (ascetic). They are not shown to be countrified shepherds as in the Shakespeare play. When Rangini proposes to buy a hut from the Corinequivalent, there is no talk of property and wages as in Shakespeare's play (2:4:66-95). On the contrary, the Corin-character declares that the religious retreat is exempt from the rule of money and offers her the ashram of her choice as a gift for a life-time (Annadaprasad Basu 48). Moreover, the Duke Senior of the Bengali play is shown dressed as a tapasvi (an ascetic) and performing puja (devotional rituals) regularly, Jaques's famed melancholy is recast as quasireligious abstinence, and the play ends on a sober note as Pundarik (the character corresponding to Duke Frederick) renounces the world to become a monk in spite of his daughter's tearful protests (Annadaprasad Basu 50, 104, 49-50, 132). In keeping with the religious mood of the penance grove, the Bengali play stretches out the reference to Duke Frederick's conversion into a full-fledged scene (Act 5, scene 9), with passages in Bengali and Sanskrit copiously describing the bliss and glory of asceticism (Annadaprasad Basu 127-32).

The Sanskrit play is evoked by the Bengali one through several scattered echoes, mostly of an ornamental nature. In Act 3 of Abhijñānaśākuntalam, the heroine Śakuntalā is reported to be "gone down with heatstroke" (32), but she is actually lovestruck and pining for Duṣyanta, who spies on her as she is "resting on a smooth rock covered in flowers" (33), with her "[1]imbs cushioned on flowers - / Bruised lotuses ..." (38). He also observes that "[h]er breasts are smeared with lotus balm" (34) for its therapeutic efficacy. Meanwhile, her friends Anasuyā and Priyamvadā affectionately fan her with lotus leaves, but she is so lovesick that she fails to notice the soothing breeze thus generated (34). The atmosphere of this scene is recalled in Ananga-Rangini especially through the details of curative measures. In order to succour the wounded and lovelorn Ananga, a still-disguised Rangini offers to take him to the cool shade of a mango tree where she has strewn the ground with the petals of lotus. She instructs Ananga to lie down on the ground placing his head on her lap and promises to cover his forehead with wet lotus petals and fan him ceaselessly with a palm frond (Annadaprasad Basu 113). Duṣyanta offers Śakuntalā a similar treatment in the Sanskrit play: "Will moist air, stirred by the fans of lotus fronds / Suffice to cool and refresh you? / Or shall I massage, in my lap, your lotus-reddened 
feet?" (39) Further, in the Sanskrit play Dusyanta notes with alarm and pity that Śakuntalā's "cheeks are drawn, her bosom shrinks, / Her waist contracts, her shoulders stoop, / Her colour drains" (35). Similarly, Rangini in the Bengali play observes with great anxiety that Ananga's face has become pale, his limbs have become loose, his brows are slightly wrinkled and his lips have lost the colour of blood (Annadaprasad Basu 112-13). Rosalind does not show any comparable sign of solicitude or the eagerness to soothe the pained lover in the corresponding scene of Shakespeare's play (Act 5, scene 2); she continues instead with her juggling of words and identities.

In addition, the Bengali play's treatment of the Phoebe-equivalent, named Phullara, is more sympathetic than the Shakespearean text's approach to Phoebe, especially when Phullara is seen pining for Jnan in long stretches of verses with Sanskritic diction. She apostrophizes the moon and blames it for causing pain to lovers (Annadaprasad Basu 79), which would be reminiscent of Dusyanta's complaint in the Sanskrit play that he finds "the moon, for all its frozen marrow, / Dart[ing] solar beams" (33). Phullara's complaint here has a distinct feel of classical Sanskrit drama or love poetry, which would be recognized by the target audience. Phoebe in Shakespeare's play is not allowed such lyrical and ornamental soliloquies. Phoebe's long speech about Ganymede starting with "Think not I love him, though I ask for him" (3:5:110-36), made in the presence of Silvius, reveals Phoebe's escalating infatuation with Ganymede and her diffidence about admitting to it at that point. But Phoebe does not have any fulsome soliloquy like Phullara's where she can wallow sensuously in her lovesick sentiments. Besides, Phullara in the same scene writes a letter to Jnan on a banana leaf (Annadaprasad Basu 80), which would recall Śakuntalā etching a love letter with her nails into a lotus leaf as an outlet for her pent-up passion (37). Further, in the Bengali play Hymen is replaced by an unnamed apsarā, a celestial maiden (Annadaprasad Basu 123-24), whose kind is celebrated in Hindu mythology for ethereal beauty, eternal youth and expertise in the performing arts. This character may be faintly suggestive of Śakuntalā's mother Menakā, who is never seen in the Sanskrit play but casts her shadow over it.

It has been observed that for colonial India "the Shakespeare-Kālidāsa interface" constituted "the site for the intersection of colonial modernity and Indian traditionality perceived as classicism" (Kapoor 219). Ananga-Rangini may also be seen as encapsulating (rather obliquely and succinctly) within its remit a popular topic of $19^{\text {th }}$-century Bengali criticism, namely, the comparison between Kālidāsa and Shakespeare as poets and/or dramatists. One of the pioneering contributions to this topic in Bengali was made by Bankimchandra Chattopadhyay in his essay Śakuntalā, Miranda evam Desdemona, originally published in the monthly Bangadarshan in 1875. In this essay Bankimchandra famously finds the unmarried Sakuntala to be similar to Miranda and the married Sakuntalā to be similar to Desdemona (88). In the same essay, he remarks that 
Shakespeare's play is like an ocean, profound, tempestuous and formidable, while Kālidāsa's is like a nandankanan (heavenly garden), which can boast of everything beautiful and pleasant but cannot partake of the sublime (87). Although Bankimchandra does not point this out directly, this distinction between Shakespeare and Kālidāsa is an especially unmistakable one because tragedy as a genre or worldview was beyond the latter's purview and horizon of expectations, while Shakespeare was the supreme exemplar of the tragedy for the $19^{\text {th }}$-century Bengali reader. The Sanskrit scholar and educationist Haraprasad Shastri in an essay originally published in the monthly Bangadarshan in 1878 seconds Bankimchandra's opinion when he argues that Kâlidāsa delineates only the beautiful aspect of the human heart, whereas Shakespeare is unparalleled in his lifelike depiction of the complexities, inconsistencies and irregularities of the human heart, in the creation of rounded and realistic human beings (138-39). The dramatist Kshirodprasad Vidyavinod (1863-1927) in an 1895 essay also regards Kālidāsa as a poet of beauty and Abhijñannaśākuntalam as the consummate embodiment of beauty (545), although he considers Bhavabhūti $\left(8^{\text {th }}\right.$ century CE Sanskrit poet) to be more accomplished than Kālidāsa in poetry (546). The philosopher and politician Hirendranath Dutta seems to be in perfect agreement with Bankimchandra's thesis as he declares Kālidāsa to be the supreme poet of beauty and his faculty for feeling beauty to be super-human (Kälidāsa o Shakespeare, 2:250; 8:750). On the other hand, Rabindranath Tagore in his essay Śakuntala (originally published in the monthly Bangadarshan in 1902) prominently departs from this favourable estimation of Shakespeare. He praises Abhijñānaśäkuntalam for showing a deep emotionalspiritual bond between human beings and the non-human Nature, and, by contrast, he critiques The Tempest for representing what he takes to be man's unabashedly predatorial and colonizing approach towards Nature (728-29). Rabindranath summarizes, "One finds only daman ["subjugation"] and peedan ["persecution"] in The Tempest-in Śakuntalā, only love, peace, amity" (726).

The play Ananga-Rangini is not in a position to address so decisively the apparently entrenched aesthetic preferences or cultural tendencies for appreciating Shakespeare and Kālidāsa in colonial Bengal. But this Bengali play tries to negotiate one received classic (Shakespeare) with the help of registers borrowed from another (Kālidāsa). Supriya Chaudhuri sees the reception of Shakespeare in India as characterized by the co-presence of three different kinds of time- "the 'universal' time of the classic, the sedimented time of history, and the time of a reformed present" (102). For the $19^{\text {th }}$-century Western-educated Bengali intellectual, Kālidāsa (as re-introduced through Orientalist scholarship) too would inhabit all these three times and be open for re-appropriation. The fact that the Bengali play in question affiliates itself both to an early modern English play and a classical Sanskrit one gives a measure of its participation in the necessarily hybrid and multi-accentual colonial modernity of $19^{\text {th }}$-century Bengal. 
Taking a cue from the Bengali play's unacknowledged and inchoate appropriation of Abhijñanasiáakuntalam, it is possible to see Ananga-Rangini as hosting in its adaptation of the Shakespeare play some of the gender politics that also informs the Sanskrit play. Romila Thapar sums up the many avatars of Śakuntalā across texts noting that,

[t]he mother of a hero in an äkhyāna and the self-reliant woman of the Mahäbhärata had been transmuted into the romantic ideal of upper caste high culture in the play by Kālidāsa, then cast as the child of nature in German Romanticism, and ended up as the ideal Hindu wife from the perspective of Indian nationalism and its perceptions of Hindu tradition. (257)

Thapar also looks askance at Rabindranath's fervent reading of Abhijñannaśäkuntalam, where she locates a patronizing scheme of $\sin$ and expiation. She summarizes it thus: "The child of nature was an innocent girl who was led astray, but she remained submissive, long-suffering, patient and still devoted to her husband and was finally exonerated" (262). The fetishization of passivity and meekness as feminine virtues that Thapar ascribes to Rabindranath's reading of Śakuntalā has been marked more recently by another scholar, Shampa Roy, to be a key principle of William Jones's rendition of the play. According to her argument, the reshaping of Kālidāsa's heroine by Jones through deliberate mistranslation:

seems to echo writings like Edmund Burke's Philosophical Enquiry into the Origin of the Sublime and the Beautiful for instance which naturalises an aesthetic ideal in which feminine beauty is inseparable from weakness, softness, compliance, fragility and dependence. It also seems to draw from the burgeoning field of conduct literature that was positioning similar ideals of the most repressive standards of female propriety or from those conservative fictions of the time in which romantic love is represented in ways that make it incompatible with female sexual agency. (Roy 68)

The same critic also contends that Jones's rendition emphasizes Śakuntalā's "rusticity," implying a Rousseauistic model of closeness to Nature and freedom from the guiles and artifices of civilization (Roy 68). She goes on to claim that

[i]t is in fact this Śakuntalā-pastoral maiden, innocent, exotic, a near fantasy creature closely associated with nature-that the German Romantics chose to respond to and appropriate for their purposes, that Goethe, Schlegel and Herder raved about and that was closely intertwined with their image of India as profoundly spiritual, idealistic and mystical. (Roy 69)

Moreover, G.N. Devy, noted literary scholar and linguist, had suggested earlier that Abhijñānaśākuntalam has been favourably accepted by Western readers 
because the text consolidates a certain image of India that is consistent with their expectations. Devy has read the play's plot as metaphorizing the colonial encounter, where the colonized intellectual collaborates in the perpetuation of the "self-image" foisted on him by the colonizer and loses "the right to share a universe of discourse" on egalitarian terms (26-27). Devy indicates that the representation of femininity in Abhijñannaśäkuntalam is linked with the colonizer's construction of the identity of the colonized. He remarks, "One could speculate why Sir William Jones chose this play, rather than some other, like Súdraka's Mṛcchakațika (a realistic comedy in which the heroine is a strong and active character), to present India's image to the Western world" (27). Such remarks, showing the imbrication of gender and colonialism in the reception of Abhijñānaśäkuntalam can help appreciate how culturally potent the crossfertilization of this Sanskrit play with As You Like It can be.

The precept that Kālidāsa's Śakuntalā represented the ideal of feminine beauty and conduct seems to have been popular among Bengali readers in the $19^{\text {th }}$ century. The essayist Chandranath Basu (1844-1910), a leading ideologue of the Hindu revivalism of $19^{\text {th }}$-century Bengal, wrote a full-fledged treatise on this theme, called Śakuntalā-tattva ["The Philosophy of Śakuntalā"], first published in 1881 and consisting of essays (revised and enlarged for the book) published earlier in the monthly Bangadarshan. In the third chapter of the book, Chandranath cites the authority of Harriet Martineau (65) and John Stuart Mill (66) to suggest an essential, universal difference between men and women in terms of their intellectual faculties and emotional constitutions, and counts it as Śakuntalā's advantage that she does not have the sharp mind of a Portia, Rosalind or Isabella (65). He subsequently produces a chart at the end of the chapter, cataloguing the insights about the differences between men and women that he has secured by analyzing the character of Śakuntalā. The chart deserves quotation in full, because such an overt and confident declaration of gendered ideology is not always easy to come by.

1. Man's body is strong; woman's body is weak.

2. Man is endurant because of bodily strength; woman is endurant because of the strength of the heart. Woman is better than man in endurance.

3. Enterprising activity is a natural characteristic of man; it is a situationspecific characteristic of woman.

4. Man is better than woman in wisdom and bodily strength; woman is better than man in the strength of the heart. Man's character has the quality of expansiveness; woman's character has the quality of depth. Man is less capable of self-absorption, feeling the external world and totally identifying with the external world; woman has all these qualities to an incalculable degree.

5. Woman's spirituality is deeper than man's. But man's spirituality is relatively independent; woman's spirituality is dependent on the material world. 
6. Man's intelligence is a result of his power of judgement; woman's intelligence is only an expression of her heart.

7. Woman is a reservoir of opposites - she is tough in spite of being soft, strong in spite of being weak, injudicious in spite of being intelligent, dependent on the material world in spite of being spiritual. There is no mystery in the world like woman. (Chandranath Basu 67)

At the conclusion of the chapter, Chandranath commends Abhijñānaśäkuntalam for illustrating the characteristics of man and woman so precisely and elegantly within its limited space. He also declares that the play proves Kālidāsa's matchless artistic merit and his superiority to Shakespeare (Chandranath Basu 67-68).

All the expectations of the ideal Hindu womanhood as derivable from Abhijñānaśākuntalam are not strictly imposed on Shakespeare's heroine by the Bengali adaptation, but they are in effect brought to a dialogue with the Shakespearean legacy that is retained in the play. To be sure, As You Like It itself gestures towards matrimony and heterosexual domesticity (at least provisionally) as a most desirable state of affairs. Jean E. Howard aptly notes that the play "dissects the problems of marriage, but many marry at the end" (592), just as many re-join court life at the end despite being conscious of its pitfalls (591). The Bengali play, in fact, emphasizes the importance of matrimony much more than As You Like It does. The title page of the play quotes six lines from Hymen's song, beginning with "Wedding is great Juno's crown, / O blessèd bond of board and bed" (5:4:130-31), thus announcing the bliss of matrimony to be one of its principal themes. Besides, as has been already discussed, the Bengali play also tries to pigeonhole Rangini into the role of the ideal wife: she is full of utmost solicitude for the wounded and indisposed Ananga, and she is speechless in remorse for deceiving him in her transvestite avatar. Additionally, Ananga-Rangini has a non-Shakespearean scene (Act 5, scene 6) where six holy hermits expatiate upon the great happiness associated with the day of wedding (121-22). There's another additional short scene (Act 5, scene 8) where Rangini's father, as would be expected of a Bengali father giving her daughter away in marriage, enquires if the newly-weds have dined and if the guests have been adequately entertained (Annadaprasad Basu 124-25). In the final scene of the Bengali play, a hermit blesses Rangini after her wedding, "As Lord Narayan reigns in Vaikuntha with Goddess Lakshmi, as Lord Shiva reigns in Kailasa with Goddess Durga, as Lord Indra reigns in heaven with his wife, so you accede to the throne with your husband and glorify the capital of the kingdom," while another hermit wishes that Rangini and Sarala may have worldconquering sons (Annadaprasad Basu 126). In absence of the sexually polyvalent Epilogue, the Bengali play privileges the heteronormative closure as an exclusive choice. A happy and prosperous married life is suggested unequivocally to be the best situation Rangini and Sarala can aspire to within the available cultural paradigm. 
Ananga-Rangini seems to admit of a lesser degree of experimentation with social roles and cultural fixtures than As You Like It attempts. But the Bengali play does manage to enlist the precedent of Shakespeare's Rosalind in order to explore some possibilities of female self-expression, to which it would otherwise have no access. The Rosalind-figure in Ananga-Rangini is identifiable as a woman character who in her final role as a submissive lover/wife is consistent with the prevalent expectations of the $19^{\text {th }}$-century Bengali culture that the play caters to. What Ananga-Rangini loses in terms of aesthetic appeal because of its reformulation of Shakespeare's heroine, it gains in terms of the Rosalind-character's congruence with the ideal of femininity that is perceptible in the reception of Abhijñānaśākuntalam in $19^{\text {th }}$-century Bengal. AnangaRangini negotiates, refashions and co-opts both Shakespeare and Kālidāsa in order to achieve a composite model of fictive femininity that would be consistent with the aesthetic tastes and cultural expectations of the Shakespeareand Kālidāsa-reading Bengali audience of its time. The Bengali play, in its cross-fertilization of literary influences from two culturally and aesthetically distinct texts, constitutes a significant (but hitherto underappreciated) case in the history of aesthetic adaptations and cultural mediations of Shakespeare.

Note: All quotations in English from Abhijñānaśākuntalam are keyed to W.J. Johnson (trans.), The Recognition of Śakuntalā, by Kālidāsa (Oxford: Oxford University Press, 2001). All Shakespeare quotations are from Stephen Greenblatt, Walter Cohen, Jean E. Howard and Katharine Eisaman Maus (eds.), The Norton Shakespeare Based on the Oxford Edition (New York: W.W. Norton, 1997). All translations from Bengali into English are by the author of this article unless otherwise indicated. The present essay follows throughout, for all Bengali persons mentioned by it, the Bengali convention of referring to a person by her given name rather than her family name.

\section{WORKS CITED}

Ahsan, Nazmul. Shakespeare Translations in Nineteenth-Century Bengali Theatre. Dhaka: Bangla Academy, 1995.

Basu, Annadaprasad. Ananga-Rangini. Kolkata: Victoria Press, 1304 BS.

Basu, Chandranath. Śakuntalā-tattva. $2^{\text {nd }}$ edn. Kolkata: Gurudas Chattopadhyay, 1296 BS.

Bharucha, Rustom. The Politics of Cultural Practice: Thinking through Theatre in an Age of Globalization. New Delhi: Oxford University Press, 2003.

Bhattacharya, Devipada. Girish Chandra Ghosh: Sahitya-Sadhana ["The Literary Career of Girish Chandra Ghosh"]. Girish Rachanavali ["The Collected Works of Girish Chandra Ghosh"]. Ed. Devipada Bhattacharya. Vol. 1. Kolkata: Sahitya Samsad, 1969. xxxvii-lxxvi. 
Brown, Steve. "The Boyhood of Shakespeare's Heroines: Notes on Gender Ambiguity in the Sixteenth Century." Studies in English Literature, 1500-1900 30.2 (Spring 1990): 243-63.

Callaghan, Dympna. Shakespeare without Women: Representing Gender and Race on the Renaissance Stage. London: Routledge, 2000.

Chattopadhyay, Bankimchandra. Śakuntalā, Miranda evam Desdemona ["Śakuntalā, Miranda and Desdemona"]. Bibidha Prabandha ["Assorted Articles"]. By Bankimchandra Chattopadhyay. Ed. Brajendranath Bandyopadhyay and Sajanikanta Das. Kolkata: Bangiya Sahitya Parishat, 1938. 80-88.

Chattopadhyay, Kshirodbihari. Kapalkundala o Miranda ["Kapalkundala and Miranda"]. Bharatbarsha 6.1.6 (Agrahayan 1325 BS): 732-41.

Chaudhuri, Bhaskar. Bikalpa Jounata O Bangla Sahitya ["Alternative Sexuality and Bengali Literature"]. Diss. Jadavpur University, 2015.

Chaudhuri, Supriya. "Remembering Shakespeare in India: Colonial and Postcolonial Memory." Celebrating Shakespeare: Commemoration and Cultural Memory. Ed. Coppélia Kahn and Clara Calvo. Cambridge: Cambridge University Press, 2015. 101-20.

Das, Sisir Kumar. A History of Indian Literature, 1800-1910: Western Impact: Indian Response. New Delhi: Sahitya Akademi, 1991.

DasGupta, R.K. "Shakespeare in Bengali Literature." Indian Literature 7.1 (1964): 16-26.

Datta, Saubhik. Shakespeare and the Bengali Drama. Diss. University of Calcutta, 2009.

Devy, G.N. After Amnesia: Tradition and Change in Indian Literary Criticism. Hyderabad: Orient Longman, 1992.

Dusinberre, Juliet. Introduction. As You Like It. By William Shakespeare. Ed. Juliet Dusinberre. The Arden Shakespeare Third Series. London: Thomson Learning, 2006. 1-142.

Dutt, Bishnupriya and Urmimala Sarkar Munsi. Engendering Performance: Indian Women Performers in Search of an Identity. New Delhi: Sage, 2010.

Dutta, Hirendranath. Kālidāsa o Shakespeare ["Kālidāsa and Shakespeare"]. Part 2. Sahitya 3.4 (Shravan 1299 BS): 243-50.

Dutta, Hirendranath. Kālidāsa o Shakespeare ["Kālidāsa and Shakespeare"]. Part 8. Sahitya 3.12 (Chaitra 1299 BS): 741-50.

Dutta, Hirendranath. Shakespeare. Part 3. Sahitya 9.8 (Agrahayan 1305 BS): 476-90.

Gangopadhyay, Abinaschandra. Girish Chandra: Banga-Natyashalar Itihas-Sambalita ["Girish Chandra: With a History of the Bengali Theatre"]. Ed. Swapan Majumder. Kolkata: Dey's Publishing, 1993.

Ghosh, Girish Chandra. Purush Angshe Nari Abhinetri. Girish Rachanavali ["The Collected Works of Girish Chandra Ghosh"]. Ed. Devipada Bhattacharya. Vol. 3. Kolkata: Sahitya Samsad, 1972. 820-23.

Ghosh, Manmathanath. Jyotirindranath [a biography of Jyotirindranath Tagore]. Kolkata: Adi Brahmo Samaj Press, 1334 BS.

Ghosh, Rina. Shakespeare-Anuvad o Anuvad Samasya ["Shakespeare Translation and Its Problems"]. Kolkata: Sanskrit Pustak Bhandar, 1975. 
Gray, Louis H. The Viddhaśālabhañjikā of Rājaśekhara, now first translated from the Sanskrit and the Prākrit. Journal of the American Oriental Society 27 (1906): $1-71$.

Howard, Jean E. Introduction to As You Like It. The Norton Shakespeare Based on the Oxford Edition. Ed. Stephen Greenblatt, Walter Cohen, Jean E. Howard and Katharine Eisaman Maus. New York: W.W. Norton, 1997. 585-93.

Jardine, Lisa. Still Harping on Daughters: Women and Drama in the Age of Shakespeare. Hemel Hempsted: Harvester Press, 1983.

Johnson, W.J. Introduction. The Recognition of Śakuntalā. By Kālidāsa. Trans. W.J. Johnson. Oxford: Oxford University Press, 2001. ix-xxix.

Kapoor, Himani. "Mapping Shakespeare and Kalidasa: Early Indian Translations." Performing Shakespeare in India: Exploring Indianness, Literatures and Cultures. Ed. Shormistha Panja and Babli Moitra Saraf. New Delhi: SAGE Publications India, 2016. 217-238.

Lal, Ananda and Sukanta Chaudhuri, eds. Shakespeare on the Calcutta Stage: A Checklist. Kolkata: Papyrus, 2001.

Latham, Agnes. Introduction. As You Like It. By William Shakespeare. Ed. Agnes Latham. The Arden Shakespeare. London: Methuen, 1975. lx-xcv.

Majumder, Srishchandra. Miranda o Kapalkundala ["Miranda and Kapalkundala"]. Bangadarshan 7.76 (Shravan 1287 BS): 145-61.

Malagi, R.A. "Toward a Terrestrial Divine Comedy: A Study of The Winter's Tale and Shakuntalam." India's Shakespeare: Translation, Interpretation and Performance. Ed. Poonam Trivedi and Dennis Bartholomeusz. New Delhi: Pearson Education, 2006. 110-26.

Mitra, Sanat Kumar. Shakespeare o Bangla Natak ["Shakespeare and Bengali Drama"]. Kolkata: Pustak Bipani, 1983.

Orgel, Stephen. "Ganymede Agonistes." GLQ: A Journal of Lesbian and Gay Studies 10.3 (2004): 485-501.

Rackin, Phyllis. "Androgyny, Mimesis, and the Marriage of the Boy Heroine on the English Renaissance Stage.” PMLA 102.1 (January 1987): 29-41.

Raha, Kironmoy. Bengali Theatre. New Delhi: National Book Trust, India, 2001.

Richmond, Hugh Macrae. Shakespeare's Theatre: A Dictionary of His Stage Context. New York and London: Continuum, 2004.

Roebuck, Thomas. The Annals of the College of Fort William. Kolkata: Hindustanee Press, 1819.

Roy, Shampa. “'The Celestial Fruit of Collected Virtues': A Reading of William Jones' Sacontalá." Revisiting Abhijñānaśākuntalam: Love, Lineage and Language in Kālidāsa's Nātaka. Ed. Saswati Sengupta and Deepika Tandon. Hyderabad: Orient Blackswan, 2011. 54-74.

Sedinger, Tracey. "“'If Sight and Shape be True”: The Epistemology of Crossdressing on the London Stage." Shakespeare Quarterly 48.1 (1997): 63-79.

Sen, Sukumar. Bangla Sahityer Itihas ["The History of Bengali Literature"]. Vol. 3. Kolkata: Eastern Publishers, 1366 BS.

Sengupta, Saswati and Deepika Tandon. Introduction. Revisiting Abhijnānaśākuntalam: Love, Lineage and Language in Kālidāsa's Nātaka. Ed. Saswati Sengupta and Deepika Tandon. Hyderabad: Orient Blackswan, 2011. 1-14. 
Shahriyar, Abu (trans.). Apnar Jeman Pachhanda [Bengali translation of As You Like It]. William Shakespeare-er Duti Natak ["Two Plays by William Shakespeare"]. Trans. Abu Shahriyar. Dhaka: Parijat Prakashani, 2012. 89-175.

Shakespeare, William. As You Like It. The Norton Shakespeare Based on the Oxford Edition. Comedies. Ed. Stephen Greenblatt, Walter Cohen, Jean E. Howard and Katharine Eisaman Maus. New York: W.W. Norton, 1997. 594-651.

Shastri, Haraprasad. Kālidāsa o Shakespeare ["Kālidāsa and Shakespeare"]. Haraprasad Shastri Rachana-Sangraha ["The Collected Works of Haraprasad Shastri"]. Ed. Debaprasad Bhattacharya. Vol. 5. Kolkata: Nath Brothers, 1984. 137-52.

Tagore, Rabindranath. Śakuntalā. Rabindra-Rachanavali ["The Collected Works of Rabindranath Tagore"]. Vol. 3. Kolkata: Visva-Bharati, 1987. 723-33.

Tagore, Sudhindranath. Kapalkundala o Miranda ["Kapalkundala and Miranda"]. Sahitya 2.3 (Asharh 1298 BS): 109-13.

Thapar, Romila. Śakuntalā: Texts, Readings, Histories. New York: Columbia University Press, 2011.

The Calcutta University Calendar; 1870-71. Kolkata: Thacker, Spink and Co., 1870.

The Calcutta University Calendar; 1871-72. Kolkata: Thacker, Spink and Co., 1871.

Trivedi, Poonam. "“Folk Shakespeare": The Performance of Shakespeare in Traditional Indian Theater Forms." India's Shakespeare: Translation, Interpretation and Performance. Ed. Poonam Trivedi and Dennis Bartholomeusz. New Delhi: Pearson Education, 2006. 152-71.

Vidyavinod, Kshirodprasad. Natak ["Drama"]. Janmabhumi 5.9 (Bhadra 1302 BS): 531-49.

Wilson, Horace Hayman. Select Specimens of the Theatre of the Hindus, Translated from the Original Sanskrit. Vol. 2. $2^{\text {nd }}$ edn.; London: Parbury, Allen, and Co., 1835.

Yajnik, R.K. The Indian Theatre: Its Origin and Its Later Development Under European Influence: With Special Reference to Western India. London: George Allen \& Unwin, 1933.

Zimmerman, Susan. "Disruptive Desire: Artifice and Indeterminacy in Jacobean Comedy." Erotic Politics: Desire on the Renaissance stage. Ed. Susan Zimmerman. New York: Routledge, 1992. 39-63. 